\title{
Behavioral Data, Cultural Group Selection, and Genetics
}

\section{QUERY SHEET}

Q1: Au: Please provide the page, edition, and volume of the reference.

Q2: Au: Please provide the edition, page, and volume of the reference. 


\title{
Behavioral Data, Cultural Group Selection, and Genetics
}

\author{
Joseph Henrich \\ University of British Columbia \\ Vancouver, British Columbia
}

Kasser et al. pose an important and often unaddressed question: how do different institutional forms, or economic systems, shape the ideas, values, beliefs, motivations, and practices of their members or partic-

25 ipants .(also see Bowles, 1998). While I applaud their efforts in opening up this line, I offer two concerns. First, Kasser et al. neglected two large-scale comparative projects that directly test their principle hypotheses and arrive at quite different conclusions. Second, 30 much of their evidence involves relationships among variables drawn from samples within one ACC populations, yet their hypotheses seem to demand comparisons among populations with differing exposure to ACC institutions. This may have resulted in faulty 35 causal inferences.

The authors hypothesize that ACC institutions, collectively forming the capitalist economic system, favor the transmission of cultural representations that promotes self-interest, competition, and materialism,

40 while suppressing the acquisition of representations related to altruism, fairness, cooperation and numerous aspects of psychological well-being. In my view, the proper test of such hypotheses would involve a systematic comparative study, preferably using behavioral

45 measures of self-interest, fairness, etc., from populations with differing degrees of exposure to ACC institutions. It happens that my colleagues and I, over the last decade, have run two such projects, deploying behavioral experiments among 15 diverse popu-

50 lations drawn from some of the remotest corners of the globe (Henrich, 2000; Henrich et al., 2004; Henrich et al., 2005; Henrich et al., 2001; Henrich et al., 2006). Our results contradict the authors' central claims. In dictator, ultimatum, third party punishment 55 and public goods games, we used actual allocation decisions among anonymous members of these communities to measure altruism, fairness, willingness to punish unfairness, and cooperation. These decisions had real financial consequences and involved non-

60 trivial sums of real money - we typically put one-day's wage on the line (although wage labor was rare or non-existent in several of our societies). With regard to the question at hand, the findings are unambiguous: Our American samples are among the most equi65 tably minded, cooperative, and altruistic people across our 15 populations. This finding was replicated in our second project, even after several methodological adjustments.

I suspect that the difference between our results and Kasser et al.'s arises from the fact that we measured behavior, with real costs and benefits, while much of their data arises from people's rhetoric - their talk about "values" or justifications, etc. (below I will also outline some concerns about their use of behavioral data). Cultural transmission often operates on two (at least) separate channels: (1) what people do (with inferences about underlying motivations from observations), and (2) what they say (or how they explain what they do). Evidence for this comes from work done predominately in the 1960's and 1970's on altruism and social learning in psychology. Kids learn what to $d o$ - as in how altruistic to be in charitable donations-by observing the altruistic or selfish $a c$ tions of models. However, they learn what to say, or how to answer a question about motivations, values, or goals, by listening to how other people answer such questions (Bryan, Redfield, and Mader, 1971; James H. Bryan and Nancy H. Walbek, 1970; James H. Bryan and Nancy Hodges Walbek, 1970). Much of the ACC evidence may be about the rhetoric of the ACC, not the behavior or the actual underlying motivational preferences. Having lived two years of my life as an ethnographer in small-scale subsistence-oriented societies in South America and Oceania, it is clear to me that even when Americans are being altruists, they like to justify themselves with appeals to self-interest. The "norm of self-interest" is actually a norm of self-interested rhetoric.

Our experimental results are consistent with much theory in cultural evolutionary anthropology (Richerson and Boyd 2000). In considering ACC institutions, and capitalistic societies, I think Kasser et al. may have missed a crucial dynamic. Competition among institutions, societies, and organizations favors those forms that are best able to promote cooperation, stability (fairness), and trust among their members. Over the long run, and on average, these institutions, etc. will outcompete those who foster selfishness, disloyalty, and distrust among their members. What seems to occur most often is that successful cooperative institutions, 110 
organizations, and societies are preferentially imitated by less successful ones, and those aspects that favor $a$ certain kind of cooperation, fairness, and trust spread (Henrich 2004). Such processes can help explain our 115 behavioral data and differences in economic production. Of course, this is no Panglossian prescription, as competition among groups may also favor greater commitments to work, money, consumption, etc. for the same reasons. And, this certain kind of prosocial-

120 ity is not the same as the trust, loyalty, and devotion to clan, tribe, village, and extended kinship organizations that has characterized much of human history, and remains central to social life in many places. Whether these effects are judged "costs" and end up reducing 125 total happiness is certainly possible (likely even), and worthy of exploration.

Several pieces of evidence cited by Kasser et al. involve correlations between things like "materialistic values" and "generosity", based on samples taken 130 within the U.S. Such evidence, which is scattered throughout the paper, ignore the fact that often substantial amounts of the variance in such measures are accounted for by genetic variation among subjects within populations (Plomin, Defries, and McLearn 2000). The

135 correlation between materialistic values and lack of generosity, for example, might occur because the same genes that influence the acquisition of materialistic values also influence generosity. This seems especially likely since most Americans, and in particular most 140 university students, experience similar degrees of the ACC. Even if one were to show that individuals who had more contact with ACC institutions had more materialistic values and showed less generosity, the correlations could still be caused by the fact that the same 145 underlying genetic variation influences all three. Thus, the authors are using within-group correlations to support arguments of causality for differences between groups. Between-group differences, however, are often caused by quite difference factors than with-group

150 differences. Empirically, evidence supporting the authors' hypotheses will either need to control for genetic variation among individuals within groups, or compare populations with differing exposure to the ACC.

\section{Note}

Address correspondence to Joseph Henrich, Department of Psychology, Department of Economics, 155 University of British Columbia, Vancouver, British Columbia. E-mail: joseph.henrich@gmail.com

\section{References}

Bowles, S. (1998). Endogenous Preferences: The Cultural Consequences of Markets and other Economic Institutions. Journal 160 Economic Literature XXXVI, 75-111.

Bryan, J. H., Redfield, J., and Mader, S. (1971). Words and Deeds about Altruism and the Subsequent Reinforcement Power of the Model. Child Development, 42(5), 15011508.

Bryan, J. H., \& Walbek, N. H. (1970). The Impact of Words and Deeds concerning Altruism upon Children. Child Development, 41(3), 747-757.

Bryan, J. H., and Walbek, N. H. (1970). Preaching and Practicing Generosity: Children's Actions and Reactions. Child Development, 41(2), 329-353.

Henrich, J. (2000). Does Culture Matter in Economic Behavior: Ultimatum Game Bargaining Among the Machiguenga. American Economic Review, 90(4), 973-980.

Henrich, J. (2004). Cultural Group Selection, Coevolutionary Pro- 175 cesses and Large-Scale Cooperation. Journal of Economic Behavior \& Organization, 53, 3-35.

Henrich, J., Boyd, R., Bowles, S., Camerer, C., Fehr, E., \& Gintis, H. (Eds.). (2004). Foundations of Human Sociality: Economic Experiments and Ethnographic Evidence From Fifteen SmallScale Societies. Oxford: Oxford University Press.

Henrich, J., Boyd, R., Bowles, S., Camerer, C., Fehr, E., and Gintis, H., et al. (2005). 'Economic Man' in Cross-cultural Perspective: Behavioral Experiments in 15 Small-Scale Societies. Behavioral \& Brain Sciences 28.

Henrich, J., Boyd, R., Bowles, S., Gintis, H., Camerer, C., and Fehr, E., et al. (2001). In search of Homo economicus: Experiments in 15 Small-Scale Societies. American Economic Review, 91, 73-78.

Henrich, J., McElreath, R., Barr, A., Ensminger, J., Barrett, C., and Bolyanatz, A., et al. (2006). Costly Punishment Across Human Societies. Science.

Plomin, R., Defries, J., and McLearn, G. E. (2000). Behavioral Genetics: W. H. Freeman \& Company.

Richerson, P., and Boyd, R. (2000). Complex Societies: The Evolu- 195 tionary Dynamics of a Crude Superorganism. Human Nature, $10,253-289$. 